\title{
A peptide derived from TIMP-3 inhibits multiple angiogenic growth factor receptors and tumour growth and inflammatory arthritis in mice
}

\author{
Yung-Yi Chen • Nicola J. Brown • Rita Jones • \\ Claire E. Lewis • Ahmed H. Mujamammi • \\ Munitta Muthana $\cdot$ Michael P. Seed $\cdot$ Michael D. Barker
}

Received: 12 December 2012/ Accepted: 23 September 2013/Published online: 16 October 2013

(C) The Author(s) 2013. This article is published with open access at Springerlink.com

\begin{abstract}
The binding of vascular endothelial growth factor (VEGF) to VEGF receptor-2 (VEGFR-2) on the surface of vascular endothelial cells stimulates many steps in the angiogenic pathway. Inhibition of this interaction is proving of value in moderating the neovascularization accompanying age-related macular degeneration and in the treatment of cancer. Tissue inhibitor of metalloproteinases3 (TIMP-3) has been shown to be a natural VEGFR-2 specific antagonist-an activity that is independent of its ability to inhibit metalloproteinases. In this investigation we localize this activity to the C-terminal domain of the TIMP-3 molecule and characterize a short peptide, corresponding to part of this domain, that not only inhibits all three VEGF-family receptors, but also fibroblast growth
\end{abstract}

Y.-Y. Chen · N. J. Brown - C. E. Lewis ·

A. H. Mujamammi · M. D. Barker $(\square)$

Department of Oncology, Medical School, University of

Sheffield, Beech Hill Road, Sheffield S10 2RX, UK

e-mail: m.barker@sheffield.ac.uk

Present Address:

Y.-Y. Chen

School of Immunity and Infection, Institute of Biomedical

Research, University of Birmingham, Birmingham B15 2TT, UK

R. Jones - M. P. Seed

William Harvey Research Institute, Bart's and the London

School of Medicine and Dentistry, Queen Mary College

University of London, London EC1M 6BQ, UK

M. Muthana

Department of Infection and Immunity, Medical School,

University of Sheffield, Sheffield S10 2RX, UK

Present Address:

M. P. Seed

Medicines Research Group, Health, Sport and Bioscience,

University of East London, London E15 4LZ, UK factor and platelet-derived growth factor receptors. This multiple-receptor inhibition may explain why the peptide was also seen to be a powerful inhibitor of tumour growth and also a partial inhibitor of arthritic joint inflammation in vivo.

Keywords TIMP-3 - VEGFR2 - Receptor ·

Angiogenesis · Arthritis · Tumour

\section{Introduction}

Aberrant angiogenesis is now widely accepted as a key player in a variety of pathological conditions, including cancer, rheumatoid arthritis and ocular neovascularization. In the case of malignant tumours, angiogenesis facilitates tumour growth and metastasis, and in arthritis, the formation of an inflamed pannus.

Angiogenesis is a complex phenomenon that involves activation, migration and proliferation of endothelial cells, smooth muscle cells and pericytes. Various pro-angiogenic factors are involved in this process including epidermal growth factor (EGF), basic fibroblast growth factor (bFGF), platelet derived growth factor (PDGF) and the vascular endothelial growth factor (VEGF) family-VEGF-A being considered the predominant effector of angiogenesis. Vascular endothelial cells express the VEGF receptors VEGFR1 and VEGFR-2, but only VEGFR-2 appears to mediate the pro-angiogenic effects of VEGF-A [1].

The growth of new blood vessels also requires breakdown of the surrounding extracellular matrix (ECM). The principal enzymes involved in this process are the matrix metalloproteinases (MMPs). Moreover MMPs also release ECM-bound angiogenic growth factors like VEGF-A, expose pro-angiogenic integrin binding sites in the ECM, 
and generate pro-migratory ECM derived fragments [2]. The activity of MMPs in tissues is tightly regulated by their endogenous inhibitors, the tissue inhibitors of metalloproteinases (TIMPs), and over-expression of these molecules in animal models inhibits tumour growth and metastasis [3]. However a completely novel anti-angiogenic activity has also been ascribed to one of the four TIMP family members, TIMP-3. TIMP-3 has been shown to specifically bind to, and inhibit, VEGFR-2 [4].

The initial aim of this investigation was to begin to map the site(s) on TIMP-3 involved in its interaction with VEGFR-2. We show that this involves the C-terminal domain of the TIMP-3 molecule. Interestingly, a short 16 amino acid peptide sequence, that forms the truncated C-terminus of a mutant form of TIMP-3, E139X, known to give rise to the degenerative retinal disease, Sorsby's fundus dystrophy [5], also inhibited VEGF receptor-mediated signalling by endothelial cells (EC) in vitro. Additionally, unlike the normal TIMP-3 molecule, the peptide also moderated their responses to bFGF and PDGF in vitro. Finally, we show that this TIMP-3 peptide has potent inhibitory effects on murine tumour angiogenesis and growth as well as inflammatory arthritis in vivo.

\section{Materials and methods}

\section{Proteins/peptides}

Peptides corresponding to amino acids: $\mathrm{Lys}^{123}-\mathrm{Asn}^{138}$ (KIKSCYYLPCFVTSKN) of the C-terminal domain and $\mathrm{Gly}^{69}-\mathrm{Arg}^{84}$ (GLKLEVNKYQYLLTGR) from the N-terminal domain of TIMP-3 were synthesized by Sheaf Innovations Ltd., Sheffield, UK, and termed p700 and p323 respectively. Oxidation of the disulfide bond of p700 was confirmed by mass spectrometry. A 16 amino acid biologically inert control peptide, fibrinopeptide A (FPA) [6] was purchased from Bachem Distribution Services GmbH, Hegenheimer, Germany.

\section{Recombinant human TIMP-3 purification}

WT-TIMP-3 or N-TIMP-3 cDNA, already bearing a $3^{\prime} 6 \times$ His tag and stop codon, were sub-cloned into the pIB/V5His-TOPO vector and used to transfect High Five insect cells (Invitrogen, UK). Clones expressing the highest levels of recombinant protein were grown in suspension culture and the conditioned media collected and concentrated by ultrafiltration. Recombinant proteins were then partially purified on heparin-agarose columns (Sigma-Aldrich, UK), eluting with $0.5 \mathrm{M} \mathrm{NaCl}$ before a final purification on $\mathrm{Ni}^{2+}$-NTA-Agarose (Qiagen, UK), eluting with PBS containing $60 \mathrm{mM}$ L-histidine and $0.025 \%$ Brij-35 (pH 7.4).
The purity of the eluted proteins was confirmed by SDSPAGE followed by silver-staining and activity confirmed by reverse-zymography as previously described [7].

Solid phase binding assay

Ninety six-well plates were coated with the extracellular domain of recombinant human VEGFR-2 fused to the Fc domain of human IgG1 (rhVEGFR-2, R\&D Systems, UK) by overnight incubation followed by blocking in $5 \%$ bovine serum albumin/PBS. Recombinant human VEGF $_{165}$ (R\&D Systems, UK), TIMP-3, N-TIMP-3 or peptides derived from TIMP-3 (p323 or p700) were titrated across the plates and then biotinylated-VEGF 165 added to each well (2.4 $\mathrm{nM}$ final concentration) followed by incubation for $1 \mathrm{~h}$ at room temperature. After washing, the biotinylated-VEGF ${ }_{165}$ was detected with avidin-horse-radish peroxidase and OPD substrate (Sigma-Aldrich, UK) followed by spectrophotometry.

\section{Cells}

Human dermal microvascular endothelial cells (HuDMEC), human umbilical vein endothelial cells (HUVEC), primary human synovial cells (SC), murine mammary tumour cells (4T1), and adult human lymphatic endothelial cells (LEC) were used in this study. HUVEC were maintained in Endothelial Cell Growth Medium MV, supplemented with $0.4 \% \quad(\mathrm{v} / \mathrm{v})$ endothelial cell growth supplement/heparin (ECGS/H), $2 \%(\mathrm{v} / \mathrm{v})$ foetal calf serum (FCS), $0.1 \mathrm{ng} / \mathrm{ml}$ EGF, $1 \mu \mathrm{g} / \mathrm{ml}$ hydrocortisone, and $1 \mathrm{ng} /$ $\mathrm{ml}$ bFGF. HuDMEC and LEC were maintained in Endothelial Cell Growth Medium MV2, supplemented with $0.4 \%(\mathrm{v} / \mathrm{v})$ ECGS/H, $5 \%(\mathrm{v} / \mathrm{v}) \mathrm{FCS}, 10 \mathrm{ng} / \mathrm{ml} \mathrm{EGF}$ and $1 \mu \mathrm{g} / \mathrm{ml}$ hydrocortisone. All the primary human endothelial cells (passages 2-6 were used) and growth media were obtained from PromoCell (PromoCell, GmbH, Germany). 4T1 cells (ATCC, LGC Standards, UK) were maintained in RPMI-1640 medium (Lonza, UK) supplemented with $10 \%$ $(\mathrm{v} / \mathrm{v})$ FCS and $2 \mathrm{mM}$ L-glutamine. SC, isolated from rheumatoid arthritis patient biopsies, were a kind gift of Prof A. G. Wilson, University of Sheffield and cultured in DMEM (Lonza, UK) supplemented with $10 \%(\mathrm{v} / \mathrm{v})$ FCS and $2 \mathrm{mM}$ L-glutamine. All primary cells or cell lines were maintained at $37{ }^{\circ} \mathrm{C}$ in a humidified $5 \% \mathrm{CO}_{2}$ atmosphere.

\section{Cell proliferation assay}

Human dermal microvascular endothelial cells were serum-starved followed by incubating with p700 peptide for $1 \mathrm{~h}$ and then $0.5 \mathrm{nM}$ of $\mathrm{VEGF}_{165}$ for $24 \mathrm{~h}$ at $37^{\circ} \mathrm{C}$. Cell proliferation was determined using a BrdU cell proliferation assay kit (Merck Chemicals Ltd, Nottingham, UK). 


\section{Cell migration assay}

The ability of the p700 peptide to inhibit $\mathrm{VEGF}_{165}$-induced EC migration was determined using a multi-well Boyden chamber (Neuro Probe, Gaithersburg, USA). Briefly, serum-starved HuDMEC were treated with p700 for $1 \mathrm{~h}$, washed and plated in the upper chamber in EBM-2 medium containing $1 \%$ FCS on an $8 \mu \mathrm{m}$ fibronectin pre-coated polycarbonate filter (Neuro Probe, Gaithersburg, USA). The cells were then left to migrate across the filter for $4.5 \mathrm{~h}$ at $37{ }^{\circ} \mathrm{C}$ with media containing $0.5 \mathrm{nM} \mathrm{VEGF} \mathrm{VE}_{165}$ in the presence and absence of inhibitors in the lower chamber. After the incubation, non-migrating cells on the upper side of the membrane were scraped off and the migrated cells were stained with Hema Gurr ${ }^{\circledR}$ rapid staining kit (Merck Chemicals Ltd, Nottingham, UK). Migrated cells were counted using a light microscope at $160 \times$ magnification in three random fields per well of three separate wells.

Tube formation assay

Serum-starved HuDMEC were seeded onto Matrigel $^{\mathrm{TM}}$ matrix pre-coated 96 well plates (BD Biosciences, Cowley, Oxford, UK) at a density of $1 \times 10^{4}$ cells/well in $100 \mu \mathrm{l}$ EBM-2 medium. Peptides were then added into each corresponding well and incubated for $1 \mathrm{~h}$ at $37{ }^{\circ} \mathrm{C}$, followed by stimulated with growth factors, $0.5 \mathrm{nM} \mathrm{VEGF}_{165}, 1 \mathrm{nM}$ PDGF-BB or $1.6 \mathrm{nM}$ bFGF, to induce tubule development. The tubules formed were examined $6 \mathrm{~h}$ after stimulation under a low power $(40 \times)$ light microscope. Images were captured and analysed by measuring the average tubule length using ImageJ software (National Institutes of Health, USA).

\section{Immunoblotting}

Transfected HUVEC or HuDMEC pre-treated with $1 \mu \mathrm{M}$ test peptides for $1 \mathrm{~h}$, were stimulated with $0.5 \mathrm{nM}$ of $\mathrm{VEGF}_{165}$ for 2,5 or $10 \mathrm{~min}$. Cells were lysed and phosphorylated proteins detected by western blotting using phospho-specific antibodies to either VEGFR-2, Erk1/2 or $\mathrm{PI}_{3} \mathrm{~K}$ (New England BioLabs, UK). Band intensities were quantified using Bio-Rad Quantity One Analysis software and normalized using $\mathrm{U}$, un-stimulated control, as $0 \%$; and $\mathrm{VEGF}_{165}$, positive control, as $100 \%$ of protein phosphorylation.

\section{Phosphorylation RTK assays}

Serum-deprived HuDMEC were pre-treated with test peptides for $1 \mathrm{~h}$ and then stimulated with growth factors (0.5 nM VEGF ${ }_{165}, 1.6 \mathrm{nM}$ bFGF, $1 \mathrm{nM}$ PDGF-BB, $1.6 \mathrm{nM}$ hepatocyte growth factor, $100 \mathrm{ng} / \mathrm{ml}$ EGF or $100 \mathrm{ng} / \mathrm{ml}$ insulin-like growth factor I) for $5 \mathrm{~min}$. Cells were then lysed and phosphorylated proteins detected using (a) a receptor tyrosine kinase array (Human Phospho-Receptor Tyrosine Kinase Array Kit, R\&D Systems Ltd.) or (b) sandwich ELISA (Duo-sets, R\&D Systems Ltd.) according to the manufacturer's instructions.

Syngeneic mammary tumour model (4T1)

$10^{6} 4 \mathrm{~T} 1$ cells were subcutaneously (s.c.) implanted into the right flank of 5-6 weeks old female BALB/c mice (Charles River Laboratories, Margate, UK) and grown until the tumour size reached $100-350 \mathrm{~mm}^{3}$. The tumour sizes were measured using callipers as described previously [8]. Once the size of the tumours reached $100-350 \mathrm{~mm}^{3}$, mice were randomized into control and treatment groups and injected with either vehicle alone (PBS), $0.025,0.25$ or $2.5 \mathrm{mg} / \mathrm{kg}$ of p700 peptide in PBS, either directly into the tumour (i.t.) once per week for 2 doses; or intravenously (i.v.) every other day for 5 doses. At the end of the experiment, animals were culled and tumours and normal tissues, including lung and liver, excised and fixed with $10 \%$ neutral buffered formalin for subsequent analysis, which included general histology and quantitative measurement of microvascular density (MVD) and necrosis.

Histological analysis of 4T1 tumours: microvessel density and tumour necrosis

For MVD measurement, rabbit-anti-mouse CD31 (AbD Serotech, Kidlington, Oxford, UK) antibody was used and sections were stained according to standard immunohistological staining protocols for formalin-fixed tissue sections. Microvessel density was estimated by measuring the percentage of CD31 positive staining in the tumour sections (15 areas per tumour slide, 7 tumour slides per group) using AnalySIS ${ }^{\wedge} D$ image analysis software (Olympus, UK). For the necrotic area inside the tumour, tumour slides were stained with H\&E. Images were measured at $200 \times$ magnification, photographed (15 areas per tumour slide, 7 tumour slides per group) and analysed by AnalySIS ${ }^{\wedge} \mathrm{D}$ image analysis software (Olympus, UK).

Analysis of 4T1 metastases

Normal tissues including lung and liver were stained with H\&E to study tumour metastasis. Total number of metastases per mouse was determined as the number of metastatic foci on five sections for each animal $(n=7)$. Incidence of metastasis was calculated as the percentage of mice with one or more metastatic nodules in the tissues. Metastasis severity was scored as follows [9]: minimal ( score $0=$ no metastatic nodule), minimal (score $1=\leq 4$ 
metastatic nodules), medium (score $2=5-7$ metastatic nodules) or extensive involvement (score $3=\geq 8$ metastatic nodules). Each nodule contained $\geq 5$ nuclei.

In vitro synovial cell invasion assay

Synovial cell invasion was determined using a GFRMatrigel $^{\mathrm{TM}}$ invasion assay kit (BD Biosciences, USA). Serum-starved SC were treated with peptide for $1 \mathrm{~h}$, followed by stimulation with $100 \mathrm{ng} / \mathrm{ml}$ PDGF-BB at $37{ }^{\circ} \mathrm{C}$ for $22 \mathrm{~h}$. After incubation, non-invading cells on the upper side of the chamber were removed and the invaded cells on the lower side of the membrane were fixed with methanol and stained with Hema Gurr ${ }^{\circledR}$ rapid staining solution (Merck Chemicals, Ltd.). Cells were counted using a light microscope at $160 \times$ magnification in 3 random fields per well of 3 separate wells.

Collagen-induced-arthritis mouse (CIA) model

The CIA mouse was used to evaluate the effect of p700 in rheumatoid arthritis. Briefly, male DBA-1 mice were sensitized to bovine collagen type II in Freund's complete adjuvant, and synchronized with a boost of collagen in incomplete adjuvant on day 21 . Mice were lightly anesthetized with halothane. The base of the tail was shaved and $100 \mu \mathrm{l}$ collagen II/FCA emulsion ( $0.1 \mathrm{mg}$ M.tb., H37RA, Sigma/100 $\mu \mathrm{L}$ Freund's incomplete adjuvant, Difco; Final concentration $100 \mu$ g collagen II/100 $\mu$ L FIA) was injected intradermally to the left hand side of this site. 21 days after initial sensitization, collagen II was dissolved in acetic acid as above, emulsified 1:1 in Freund's incomplete adjuvant and $100 \mu \mathrm{L}$ injected into the base of the tail on the right hand side of the tail base. Mice were then intravenously treated with vehicle control (PBS) or p700 peptide $(2.5 \mathrm{mg} / \mathrm{kg})$ for 7 doses, i.v. every 2 days into alternating sides of tail veins from day prior to boost (day 20) to day 35.

The development of the arthritis was assessed by blind observation of 'clinical joint score' (i.e. arthritis scores) [10]. Mice were individually marked and examined from the time of the day of boost (day 21). Every inflamed main digit scored one, inflammation of the front paw scored one, inflammation of the hind paw scored one, and involvement of the ankle scored one. Thus a maximal score for each animal was 22. Animals were also assessed quantitatively for hind paw inflammation through volumetric measurement by plethysmometry (Ugo Basille Srl, Italy) and expressed as $\mathrm{mL}$ change from day 21 boost baseline. Mice with arthritis development pre boost were omitted from the final analysis. Results were also expressed as area under the curve (AUC) from day 21.
In silico modelling of the TIMP3/VEGFR2 interaction

In order to attempt to assess how TIMP3 and the p700 peptide might bind to and inhibit VEGFR2, in silico modelling of the interaction was performed. While a crystal structure for the whole of TIMP-3 is not yet available, the structures of full length TIMP1 and TIMP2 and the N-domain of TIMP3 have been solved at high resolution [11-14] enabling a model of the full length TIMP3 protein to be created using the Phyr2 Server [15] with high degree of confidence (94\% modeled at $>90 \%$ confidence). This was uploaded to the ZDOCK protein docking server [16] together with the crystal structure of the D23 immunoglobulin-homology domains of VEGFR2, that comprises the VEGFA binding site [17]. From the predicted structures, the residues present in both molecules that lie within $4 \AA$ of one another were determined using PyMOL software.

\section{Results}

Inhibition of ligand binding to VEGFR-2

We had previously found that HUVEC cells transfected with cDNA corresponding to full length TIMP3 and a highly truncated Sorsby's fundus dystrophy mutated form of TIMP3, E139X, showed reduced VEGFR2 and Erk1/2 phosphorylation in response to VEGF, whereas the same cells transfected with the $\mathrm{N}$-terminal domain showed no reduction in these responses (unpublished observation). The only difference between the N-terminal domain of TIMP-3 and the E139X mutant is a sequence of 16 amino acids $\left(\operatorname{Lys}^{123}-\mathrm{Asn}^{138}\right)$. This implicated a role for this domain in VEGFR-2 binding. In order to directly test this hypothesis a peptide corresponding to this sequence (p700), together with other TIMP-3 derived sequences, were tested for their ability to inhibit the binding of biotinylated-VEGF ${ }_{165}$ to the extracellular domain of recombinant human VEGFR-2 (Fig. 1). This showed that full length TIMP-3 and p700, but not N-TIMP-3 or p323, a 16 amino acid peptide sequence from the $\mathrm{N}$-terminal domain, were able to inhibit the binding of $\mathrm{VEGF}_{165}$ to rhVEGFR2. Complete inhibition of B-VEGF 165 was not observed for any of the proteins as increasing inhibitor concentrations much above those shown led to non-specific binding of B-VEGF $_{165}$ to the plate, possibly due to the basicity of all these peptides.

In order to confirm this effect on the endogenous VEGFR-2 receptor, a series of in vitro angiogenesis assays were performed using human dermal microvascular endothelial cells (HuDMEC). 


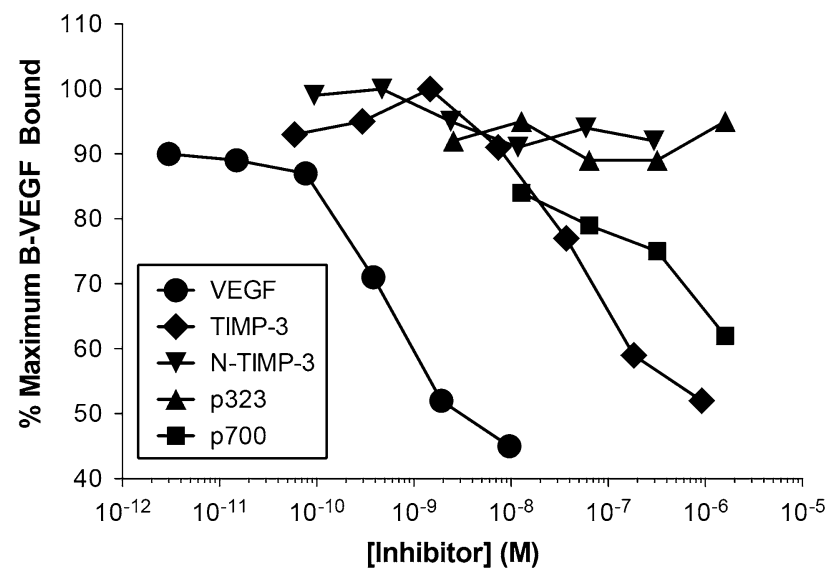

Fig. 1 The binding of biotinylated-VEGF 165 (B-VEGF) to rhVEGFR2 following pre-incubation with either unlabelled $\mathrm{VEGF}_{165}\left(\mathrm{VEGF}_{165}\right)$, WT-TIMP-3 (WT-T3), N-TIMP-3 (N-T3), p700 peptide (p700) or p323 peptide (p323) relative to the binding of B-VEGF alone

Inhibition of $\mathrm{VEGF}_{165}$-induced functional responses of HuDMEC

\section{Cell proliferation and migration}

p700 showed a dose responsive inhibition of $\mathrm{VEGF}_{165^{-}}$ induced cell proliferation (to a maximum inhibition of $40 \%$ ) and migration (maximum inhibition, $67 \%$ ) up to a concentration of $1 \mu \mathrm{M}$ (Fig. 2a, b). Concentrations of the control peptide of $10 \mu \mathrm{M}$ and above showed some toxicity to HuDMEC (as determined by propidium iodide staining - data not shown) so that the optimum dose of peptides used in subsequent experiments was $1 \mu \mathrm{M}$.

\section{Tubule formation}

Exposure to $1 \mu \mathrm{M}$ p700 virtually abolished VEGF $_{165^{-}}$ induced HuDMEC tube formation ( $>99 \%$ inhibition) (Fig. 2c). The binding of VEGF 165 to VEGFR-2 has been shown to be augmented by heparan sulfate proteoglycans (HSPG) or exogenous heparin that interacts with both molecules [18, 19]. TIMP-3 also binds to sulfated glycosaminoglycans [20], and while this does not seem to be responsible for its ability to inhibit VEGFR-2 in that TIMP-3 also inhibits responses to VEGF $_{121}$ (which lacks a heparin binding site) [4], there remained a possibility that p700, being highly basic (calculated pI 9.74), could bind to heparin, potentially affecting the ability of $\mathrm{VEGF}_{165}$ to bind to VEGFR-2. However p700 was similarly potent ( $>97 \%$ inhibition) at inhibiting tubule formation in response to $\mathrm{VEGF}_{121}$ (Fig. 2d). Addition of the peptide in the absence of VEGF had no effect on tubule formation, relative to untreated cells (data not shown).
VEGFR-2-mediated signalling

$1 \mu \mathrm{M}$ p700 significantly inhibited $\mathrm{VEGF}_{165}$-induced VEGFR-2 phosphorylation by approximately $50 \%$ and this was comparable to the inhibition by the same concentration of rhTIMP-3 (45\% inhibition) (Fig. 2e). Similarly, $1 \mu \mathrm{M}$ p700 significantly inhibited VEGF $_{165}$-induced phosphorylation of downstream kinase $\mathrm{PI}_{3} \mathrm{~K}$ by approximately $50 \%$ (Fig. 2f).

Inhibition of other growth factor receptors

A preliminary screen using a phospho-receptor tyrosine kinase array indicated p700 inhibition of additional VEGF, FGF and PDGF receptors but not the receptors for EGF, hepatocyte growth factor (HGFR/Met) or insulin-like growth factor receptors (data not shown). These data were then confirmed using a sandwich ELISA to show significant inhibition of VEGFR-1, -2 and -3 , FGFR-1, $-2 \alpha,-3$ and -4 and PDGFR- $\alpha$ with no inhibition of HGFR or insulin-like growth factor 1 receptor (Fig. 3a). Additionally p700 inhibited tubule formation in response to $\mathrm{VEGF}_{165}$, bFGF and PDGF-BB (Fig. 3b).

Effect of p700 on tumour growth

The effect of p700 on tumour growth in vivo was demonstrated in a syngeneic breast tumour model (4T1 cells) in $\mathrm{BALB} / \mathrm{c}$ mice. Tumours in both vehicle control groups (intravenous and intra-tumour injection sites) grew steadily and reached the maximum size allowable by day 24 , when the animals were sacrificed. By contrast a weekly intratumour (i.t.) dose of $0.25 \mathrm{mg} / \mathrm{kg}$ peptide or intravenous (i.v.) dose every 2 days of $0.25 \mathrm{mg} / \mathrm{kg}$ or above almost totally abolished tumour growth (Fig. $4 a, b$ ).

\section{Effect of p700 on tumour histology}

Anti-CD31 staining of the tumour sections revealed a significant (approximately 50\%) reduction in microvascular density in both treatment groups compared to that seen in the control groups (Fig. 4c, d). This may, at least in part, account for the observed inhibition in tumour growth. While there was an indication of increased necrosis and decreased metastases in the treated group, this failed to reach significance.

In vitro effects of p700 on synovial cell invasion

The growth factor receptor inhibitory profile of p700 indicated it may also have an effect on the invasive phenotype of rheumatoid arthritis synovial cells, which lack VEGFR2 [21], but respond to PDGF and fibroblast growth 
Fig. 2 p700 inhibits VEGFmediated responses in HuDMEC. p700 showed a dose responsive inhibition of a VEGF 165 -induced HuDMEC proliferation, $\mathbf{b}$ cell migration and (at $1 \mu \mathrm{M})$ almost totally abolished both $\mathbf{c} \mathrm{VEGF}_{165^{-}}$and d VEGF $_{121}$-induced tubule formation. Mean \pm SEM, $\mathrm{n}=4, * p<0.05$ compared to positive control, Mann-Whitney $U$ test). Similarly p700 inhibited VEGF $_{165}$-induced phosphorylation of eVEGFR-2 itself and $\mathbf{f}$ downstream kinase $\mathrm{PI}_{3} \mathrm{~K}$ (means \pm SEM, $\mathrm{n}=3$. ${ }^{*} p<0.05$ w.r.t. positive control, Mann-Whitney $U$ test). All data were normalized using $\mathrm{U}$, untreated cells, as $0 \%$ and VEGF only-treated cells as $100 \%$ activity. In all cases the control peptide (CP) had no significant effect
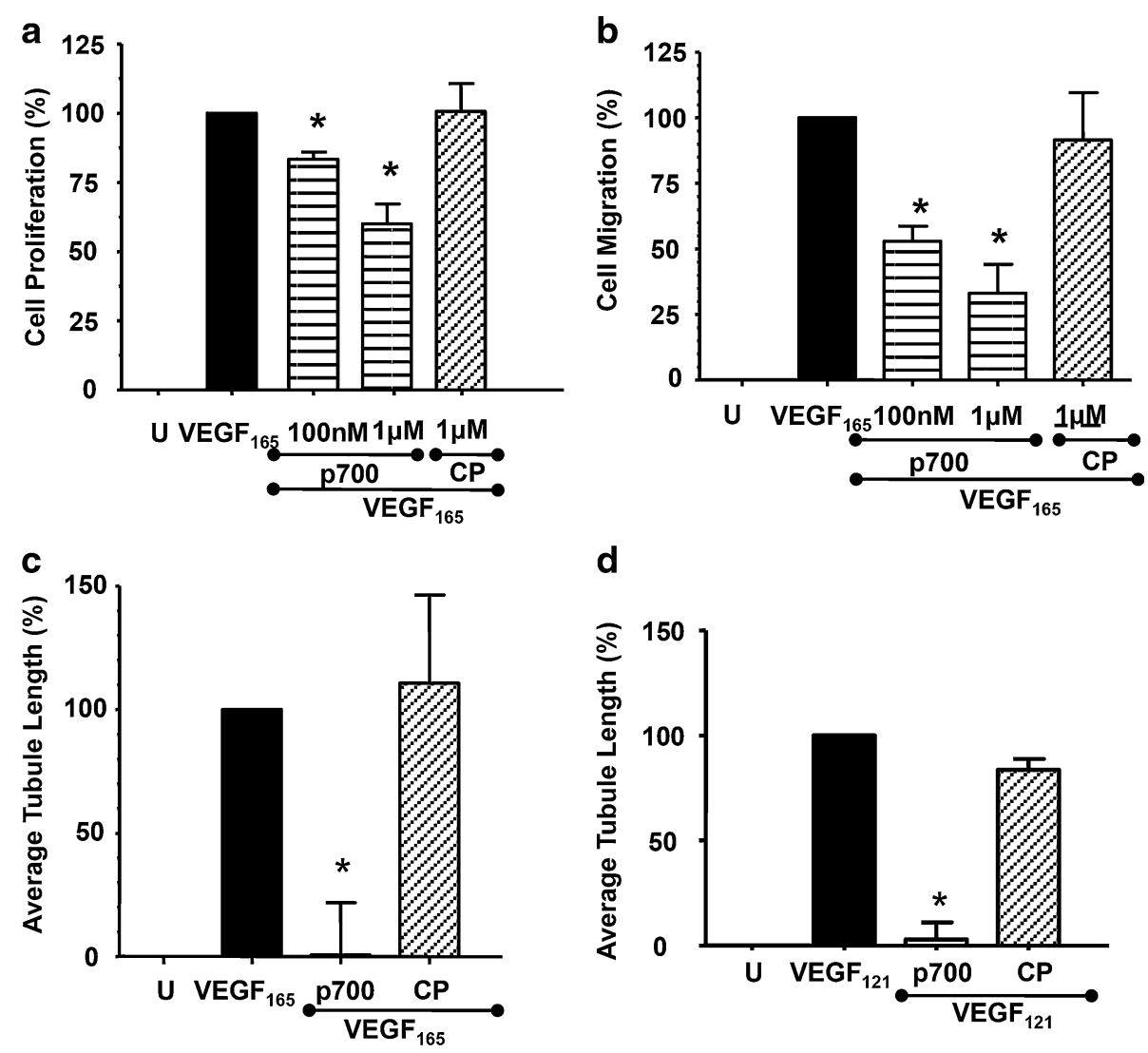

d
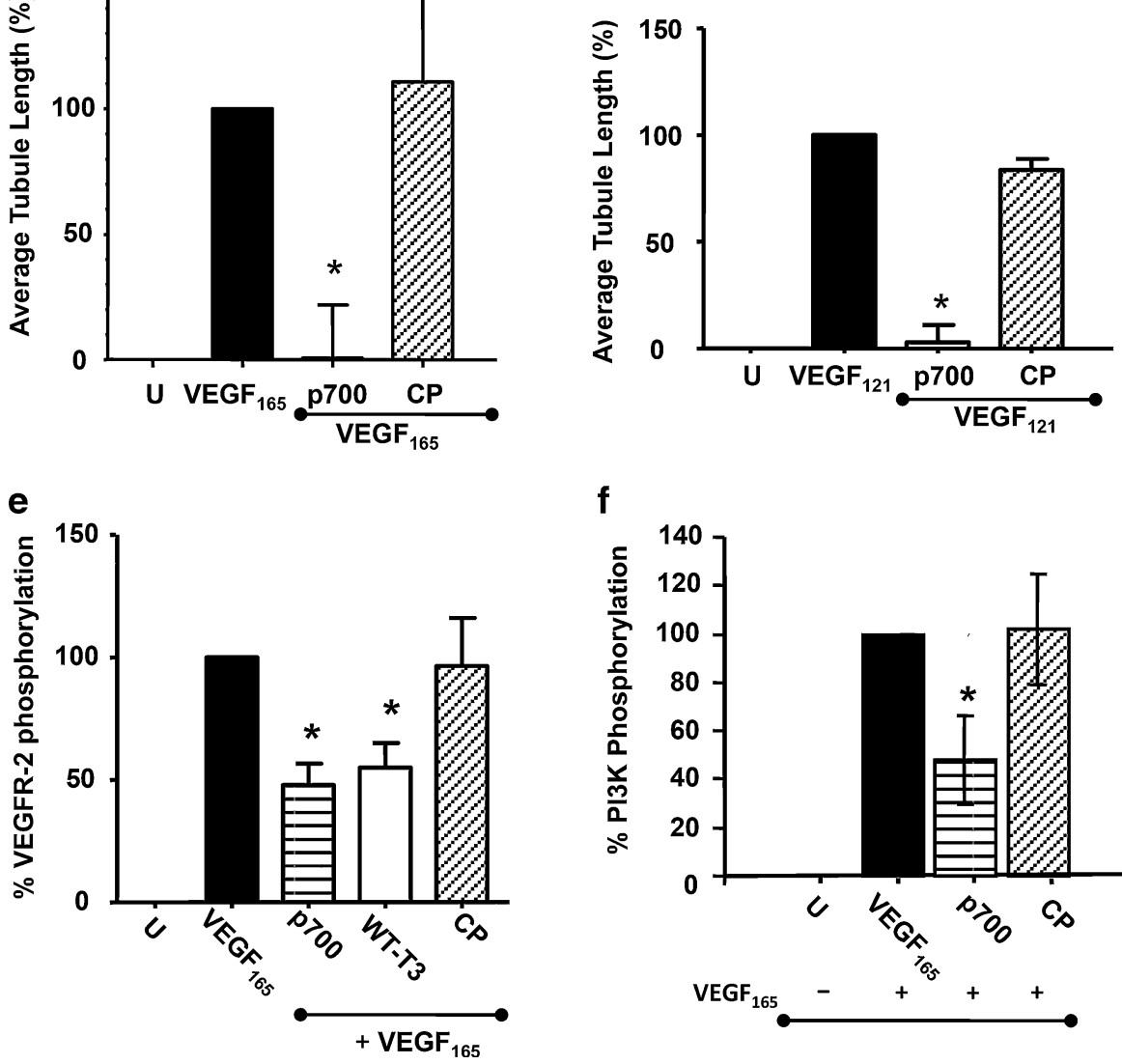

f

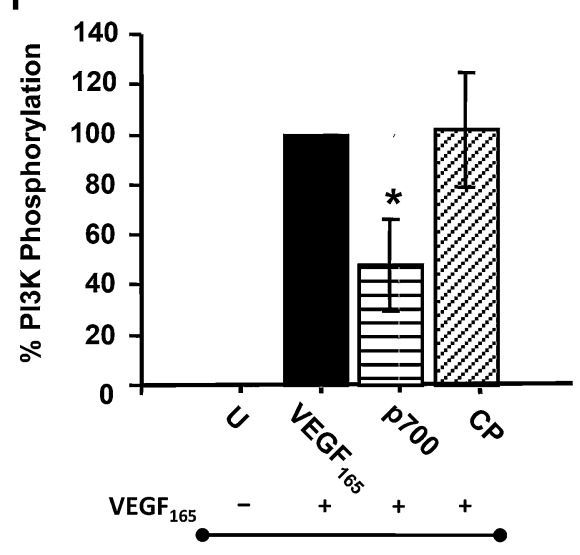

factor (FGF). While synovial cells failed to migrate through Matrigel ${ }^{\mathrm{TM}}$ in response to bFGF (data not shown), they showed marked invasion in response to PDGF-BB and this response was significantly inhibited (by approximately $40 \%$ ) in the presence of p700 (Fig. 5).

Effect of p700 on murine collagen-induced arthritis

In order to test whether the effect of p700 on synovial cell invasion would translate into a therapeutic effect in vivo, the peptide was tested in a mouse collagen-induced arthritis (CIA) model. Injections of $2.5 \mathrm{mg} / \mathrm{kg}$ p700 every 2 days significantly inhibited CIA progression (Fig. 6a, b). Both the clinical presentation of disease as well as hind paw inflammation were reduced.

In silico modelling of the TIMP3/VEGFR2 interaction

The top 5 predicted TIMP-3/VEGFR2 interactions from the ZDOC server were examined. Figure 7 a shows the known structure [17] of VEGFA bound to domains D23 of VEGFR2 and Fig. 7b, the highest scoring model of TIMP3 bound to the same receptor domains, with the p700 sequence highlighted. Figure $7 \mathrm{c}-\mathrm{f}$ show residues from the 


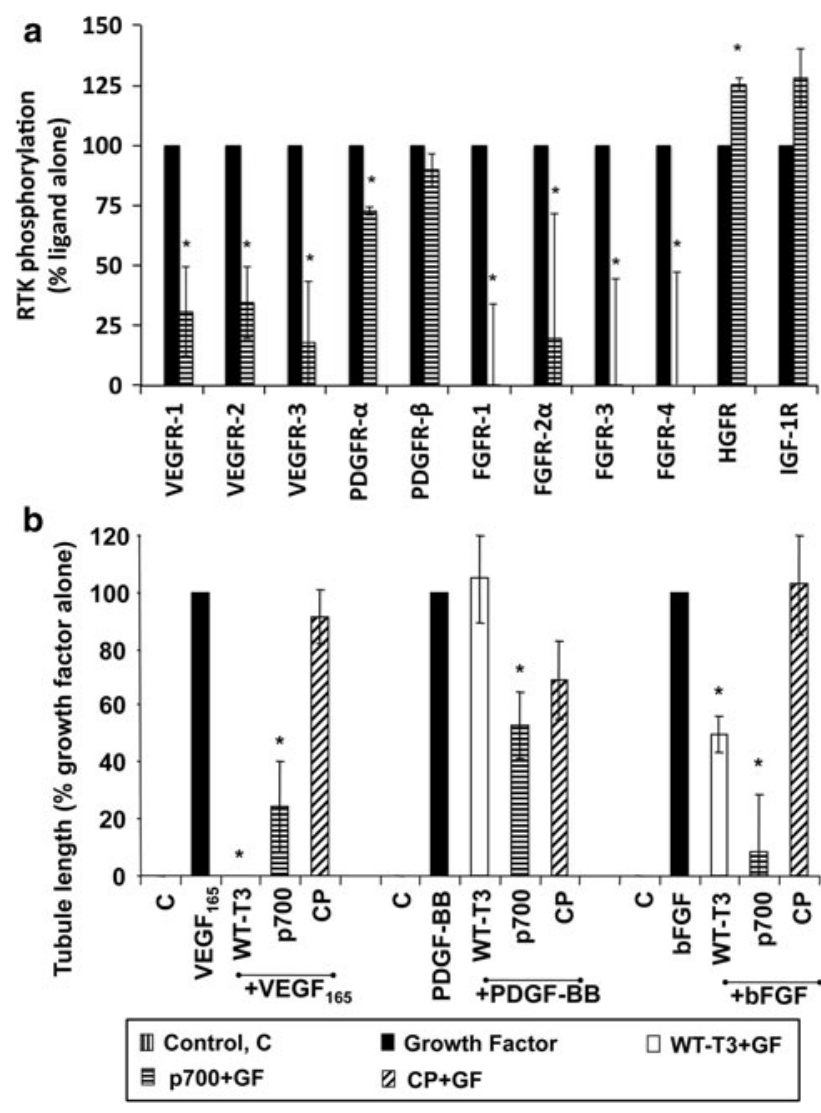

Fig. 3 p700 peptide inhibits phosphorylation of multiple tyrosine kinase receptors. a p700 peptide significantly inhibited VEGFR-1, -2 and -3 , PDGFR- $\alpha$, FGFR-1, $-2 \alpha,-3$ and -4 phosphorylation in response to their respective ligands. b p700 inhibited VEGF, bFGF and PDGF-BB stimulated tubule formation in vitro. Control peptide (CP), growth factor (GF), WT-TIMP-3 (WT-T3). Means \pm SEM, $\mathrm{n}=3 .{ }^{*} p<0.05$ w.r.t positive control (Mann-Whitney $U$ test)

N-domain, loop 4, loop 6 and the C-terminal tail of TIMP-3 respectively, and the corresponding VEGFR2 residues, that lie within $4 \AA$ of one another, highlighted in space filling mode using PyMOL.

\section{Discussion}

Initially it was assumed that the anti-angiogenic activities of TIMPs were due to their ability to inhibit MMPs. However TIMP-2 and TIMP-3 have since been shown to exhibit anti-angiogenic activities that are independent of MMP inhibition [4, 22]. For TIMP-2 this appears to be due to its ability to bind $\alpha 3 \beta 1$ integrin [23] whereas for TIMP-3 it is due to its ability to bind to and inhibit VEGFR-2 [4]. The ability of TIMP-3 to inhibit VEGFR-2 mediated angiogenesis may play a critical role in the eye, regulating vascularization of the retina $[24,25]$. Indeed specific mutations in TIMP-3 result in the autosomal dominant degenerative disease of the macula, Sorsby's fundus dystrophy (SFD), frequently characterized by abnormal retinal vascularization [26].

While the ability of TIMPs to inhibit MMPs lies within their N-terminal domain, a number of activities that are specific to individual family members, such as pro-MMP binding, have been shown to reside in the C-terminal domain [27]. The data presented here indicate that this domain is also largely responsible for VEGFR-2 inhibition. This finding supports the observation that full length and C-terminal domain TIMP-3, but not N-TIMP-3 are able to inhibit aortic endothelial cell sprouting in mice [24]. Moreover the fact that p700 was able to mimic both the anti-angiogenic effects of TIMP-3, and its ability to inhibit VEGF binding to VEGFR-2, strongly implicates this proximal region of the $\mathrm{C}$-terminus as the region that interacts with the VEGF binding site of the receptor.

The fact that TIMP-3 and p700 were less potent than unlabelled $\mathrm{VEGF}_{165}$ in competing with $\mathrm{B}-\mathrm{VEGF}_{165}$ for receptor binding may simply reflect the fact that both the recombinant VEGFR-2 and VEGF $_{165}$ are dimers, potentially resulting in a significant avidity effect, whereas TIMP-3 is monomeric. Indeed it has been observed that monovalent VEGFR-2 has an approximately 100-fold lower affinity for $\mathrm{VEGF}_{165}$ than the dimer [28].

TIMP-3 appears to bind VEGFR-2 specifically, with no inhibition of the closely related VEGFR-1, FGFR1 or PDGFR- $\beta$ receptors [4]. In contrast, the p700 sequence also significantly inhibited the phosphorylation of VEGFR-1, VEGFR-3, PDGFR- $\alpha$ and FGFR-1, $-2,-3$ and -4 by their respective ligands, as well as VEGF-A PDGF-BB and bFGF-induced tubule formation. In the latter experiment some inhibition of bFGF-induced tubule formation was also seen with TIMP-3, which is in keeping with earlier reports demonstrating TIMP-3 inhibition of both VEGF-A and FGF-mediated angiogenesis in vitro and in vivo [29]. However a more recent report from the same laboratory showed that TIMP-3 did not inhibit bFGF or PDGF-BB induced proliferation of FGFR1 or PDGFR- $\beta$-transfected porcine aortic endothelial cells respectively, or PDGF-BB induced binding or phosphorylation of PDGFR- $\beta$ in the same cells [4]. A likely explanation for this apparent discrepancy is the previously observed synergy between VEGF and FGF, whereby a significant proportion of the angiogenic effect of FGF on endothelial cells is dependent on the activity of autocrine and paracrine VEGF induced by FGF [30]. Clearly, however, this would not explain the inhibition of phosphorylation of FGF or PDGF receptors observed in our studies. Moreover, the fact that p700 potently inhibits PDGF-induced invasion of synovial cells, which lack VEGF tyrosine kinase receptors [21], confirms a direct effect on PDGFR.

The pattern of inhibition of $\mathrm{p} 700$ for additional tyrosine kinase receptors is in keeping with their structural 
Fig. 4 p700 reduces the growth of 4T1 mammary

adenocarcinoma in mice and inhibits tumour angiogenesis. Animals were injected with either PBS (vehicle control) or PBS containing $0.025,0.25$ or $2.5 \mathrm{mg} / \mathrm{kg}$ p700 peptide-either a directly into the tumour (i.t.) or b intravenously (i.v.) — at the times indicated by the arrows, and tumour size measured using callipers so that the average tumour volume could be calculated. Data are means \pm SEMs, $n=7$. At the end of the procedure, the differences in mean tumour volume between vehicle control and p700 treated groups were significant $(*$ i.t. route: $p<0.0025$ and i.v. route: $\wedge 0.025 \mathrm{mg} / \mathrm{kg}$ treated group, $p<0.05 ; * 0.25 \mathrm{mg} / \mathrm{kg}$ treated group, $p<0.02 ;+2.5 \mathrm{mg} / \mathrm{kg}$ treated group, $p<0.05$; MannWhitney $U$ test). c Tumour vasculature. Tumours from control animals (U), or p700treated (p700), were immunostained for CD31 (brown) and photographed using an Olympus light microscope. Bar $150 \mu \mathrm{m}$. $N$ necrotic area. Microvascular density (MVD) was then quantified $\mathbf{d}$ using AnalySIS^D image analysis software. The results show p700 significantly inhibits

microvascular density in both i.v. and i.t. treatment groups. Data are means \pm SEMs, $\mathrm{n}=7$ tumours/group. $* p<0.05$ w.r.t. vehicle control group (MannWhitney $U$ test)
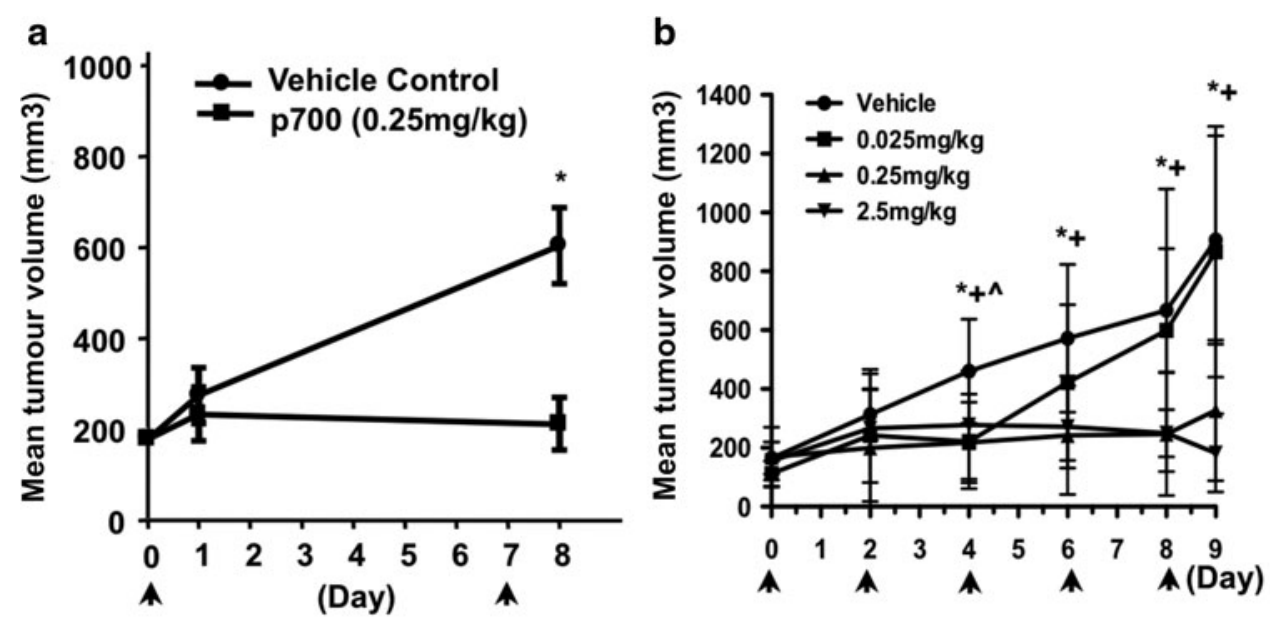

C
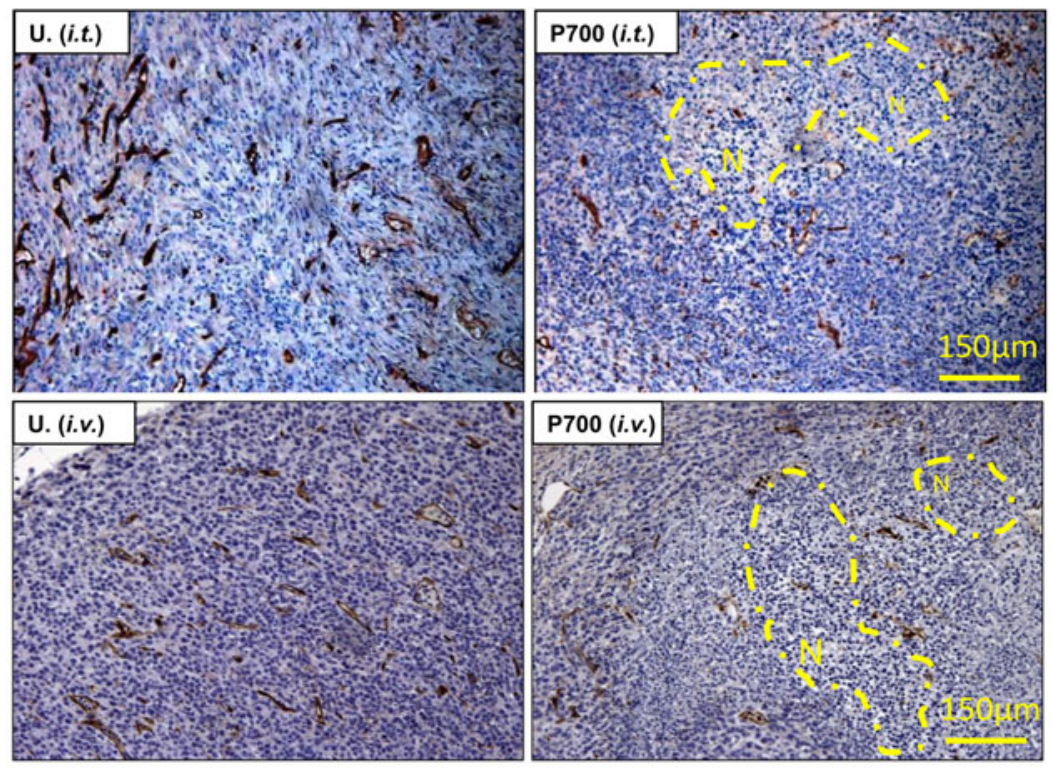

d
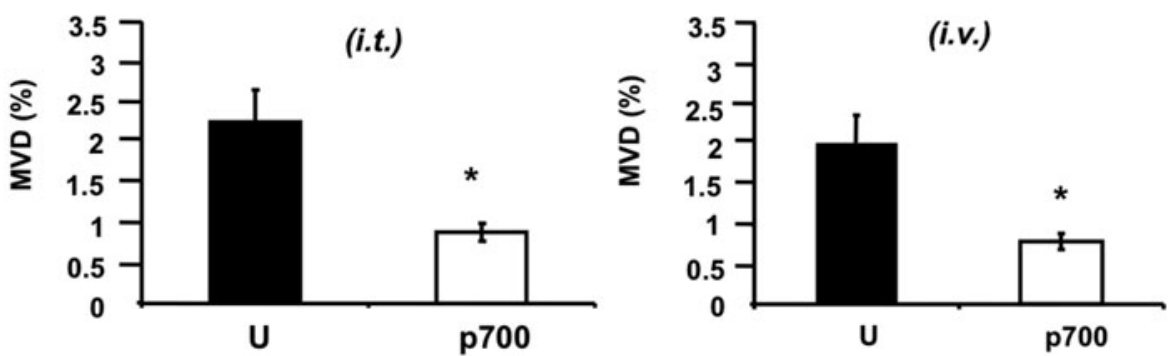

conservation [31], as all have extracellular domains comprising immunoglobulin-homology repeats, with domains 2 and 3 (D23) playing major or exclusive roles in ligand binding. In contrast EGFR, HGFR or IGF-1R, which were not inhibited by p700, lack this domain structure. Indeed the in silico modelling using ZDOC indicated that TIMP-3 potentially occupies the D23 interface in a very similar manner to the ligand. Closer examination of this model showed 2 residues found in the p700 sequence, Phe133 and
Val134 potentially in close contact with the ligand binding site. Although our data, and those recently published by Qi et al.[32], excluded the amino domain of TIMP-3 in VEGFR2 inhibition, some potential contact residues were also found there. This does not necessarily discredit the model, as it is possible these residues help stabilise the interaction but are insufficient to allow binding of N-TIMP-3 alone. However the majority of residues of TIMP-3 in contact with VEGFR2 in the model lie in the 


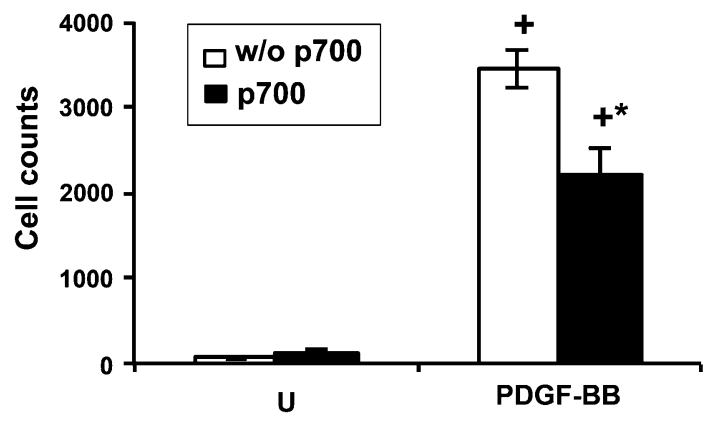

Fig. 5 p700 inhibits PDGF-BB induced synovial cell invasion. U: untreated cells with (solid bar) or without (open bar) p700; PDGFBB: Cells pre-treated with or without $\mathrm{p} 700$ and activated with PDGFBB. Pooled data are shown as means \pm SEM, $\mathrm{n}=3 .+p<0.05$ wrt $\mathrm{U} ; * p<0.05$ wrt PDGF alone (Mann-Whitney $U$ test)

carboxyl domain, with both loop 6 and the $\mathrm{COOH}$-tail sequence showing several sites of direct interaction. This is supported by the fact that peptides corresponding to these domains are also potent inhibitors of VEGFR2 [32]. While these authors failed to show inhibition with a 10 amino acid peptide corresponding to loops 4 and 5, that peptide lacks some of the residues found in p700 shown in the model to lie in the ligand binding site. The fact that p700 is highly promiscuous compared to the natural ligands, or indeed TIMP-3 itself, is presumably due to the diminutive size of the p700 peptide potentially abrogating specificity constraints of those much larger molecules.

While VEGF-A is considered the major angiogenic activator for endothelial cells, other growth factors, including bFGF [30] and PDGF-BB [33], synergize with VEGF or are directly angiogenic. Moreover angiogenesis is also dependent on pericytes and smooth muscle cells that stabilize the new vessels, and these cells respond to other growth factors, including bFGF and PDGF-BB, rather than VEGF. The latter growth factors are also potent mitogens for tumour cells [34]. These molecules may also play important roles in rheumatoid arthritis with, for example, bFGF being a potent inducer of osteoclastogenesis [35] and PDGF-BB, together with transforming growth factor beta, greatly potentiating fibroblast-like synoviocytes' response to inflammatory cytokines [36].

This wider inhibitory profile of p700 may account for the apparent potency of the molecule in preventing tumour growth in the 4T1 mouse model and, to a lesser extent, in modulating arthritis in the CIA mouse model. While there was no significant decrease in tumour metastasis in the 4T1 model, this is a highly invasive and aggressive tumour and earlier dosing may have been more effective. The fact that the efficacy of p700 in the CIA model was less dramatic than in the 4T1 tumour model is not surprising. Subclinical disease and angiogenesis already occurs by day 21 , and the boosted model provides a robust immune response. In
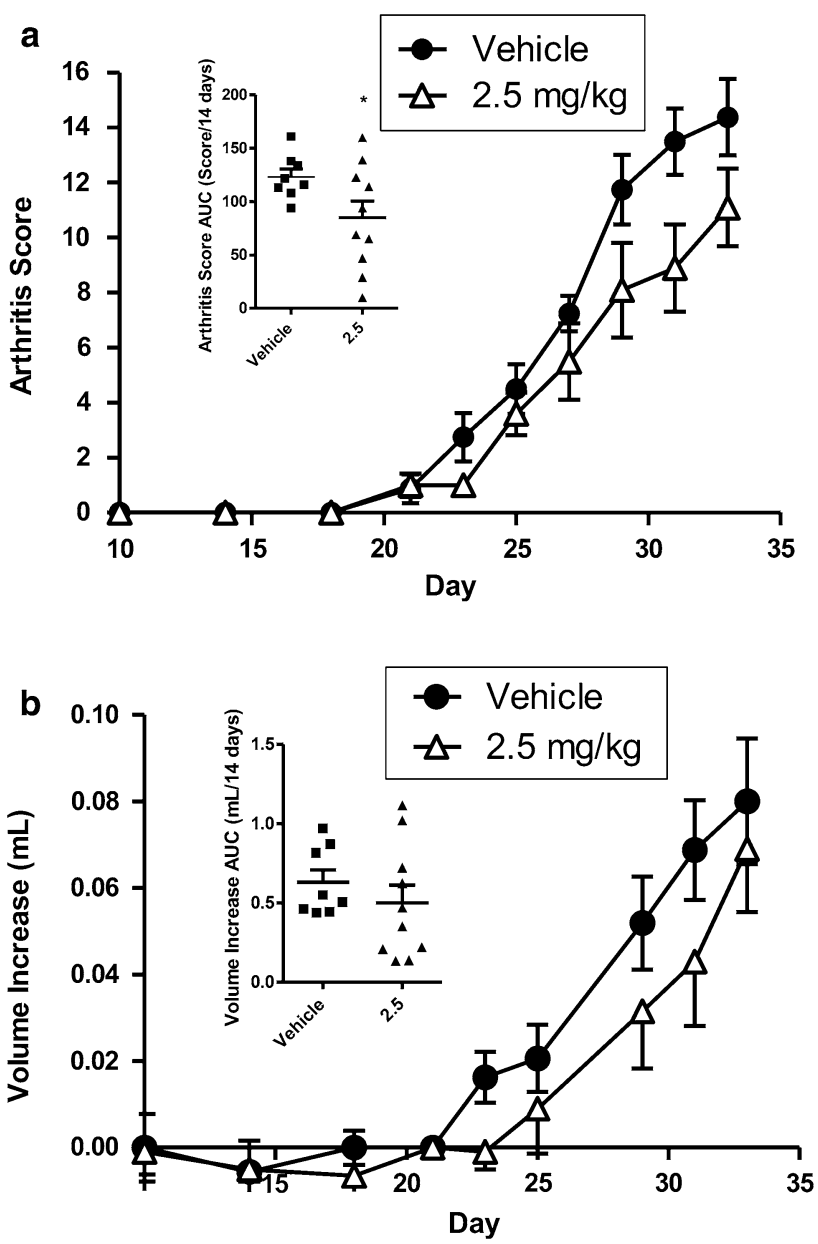

Fig. 6 The inhibition of collagen-induced arthritis by p700. Mice with CIA were dosed with vehicle or p700 at $2.5 \mathrm{mg} / \mathrm{kg}$. a Arthritis score $(p<0.001 ; 2$-way ANOVA), and area under curve (inset, $p<0.05)$ relative to vehicle alone. b Hind paw volume $(p<0.05$; 2-way ANOVA), and area under curve (inset, NS). Means \pm SEM (Vehicle $\mathrm{n}=8, \mathrm{p} 700 \mathrm{n}=10$ - points on AUC graphs are individual animals)

addition, the fibroblastic role in arthritic disease occurs in the later chronic phases of the disease. A more potent action may have been effected at a higher dose, or with daily dosing, however resources did not permit these additional regimes. Angiogenesis plays an important role in chronic inflammation [37], and its inhibition results in protection against cartilage erosion [38]. Therefore drugs targeting angiogenic/growth factor receptors may provide an additional treatment modality to those targeting the immune system alone. Interestingly, in the mouse $\mathrm{K} / \mathrm{BxN}$ model of RA, only inhibition of VEGFR-1 and not VEGFR-2 inhibits disease [39]. VEGFR-1 is also expressed by monocytes/macrophages and osteoclast precursor cells [40] and it is possible that angiogenesis and tissue damage in the rheumatoid joint is largely mediated by infiltration with these cells which then secrete further angiogenic and 

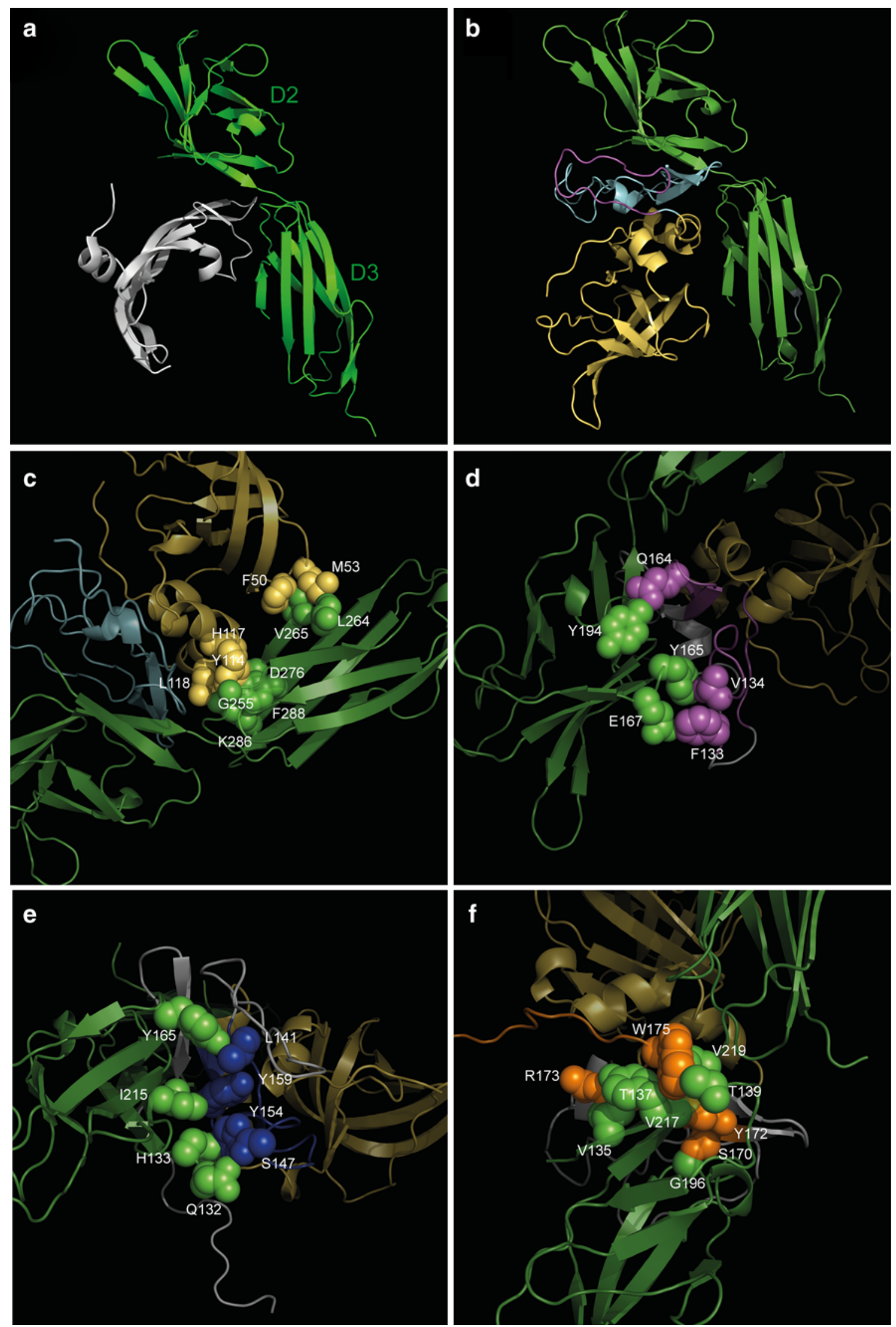
4 Fig. 7 ZDOC modelling of potential TIMP-3/VEGFR2 interactions. Residues shown as spheres on TIMP-3 and VEGFR2 lie within $4 \AA$ of one another. Domains D23 of VEGFR2 are shown in green throughout. a VEGFA (grey) bound to VEGFR2 D23 [17]. b ZDOC model of TIMP-3 (yellow $\mathrm{N}$-domain; pale blue $\mathrm{C}$-domain; purple $\mathrm{p} 700$ residues) bound to VEGFR2 D23. c TIMP-3 N-domain (yellow) binding residues. d Loop 4 TIMP-3 (purple) binding residues. e Loop 6 TIMP-3 (blue) binding residues. f C-tail peptide (orange) binding residues

catabolic factors, rather than by direct interaction with VEGFR-2 on endothelial cells.

The majority of anti-angiogenic therapies currently in clinical practice target the VEGF/VEGFR interaction and fall into two main categories. The first are antagonists that target VEGF itself, the major player being bevacizumab [41], a humanized monoclonal antibody. The second are small molecule inhibitors that target the tyrosine kinase domain of these receptors and include sorafenib and sunitinib [42]. The former have to be administered intravenously and only target VEGF-A. However VEGF-A may be replaced as an angiogenic factor by other growth factors as disease progresses, including VEGF-C and -D, which can activate VEGFR-2 after proteolytic cleavage [43], placental growth factor which specifically targets VEGFR1 [44], bFGF and PDGF [45]. The tyrosine kinase inhibitors can be taken orally and will also inhibit responses to all VEGF family members. Current drugs also inhibit several tyrosine kinase receptor family members in addition to VEGFR-2, including some intracellular signalling molecules. While this may broaden their activity against other pro-angiogenic factors it may also increase their off target effects.

The data described herein not only implicates the proximal region of the carboxyl-terminal domain of TIMP-3 in binding and inhibiting VEGFR-2, it also demonstrates the feasibility of using a single drug to target multiple tyrosine kinase receptors via their extracellular ligand binding domain, rather than their tyrosine kinase domain. This may provide an additional mode of targeting this family of receptors that potentially combines the benefits of current anti-angiogenic therapies; having a broader inhibitory profile than antibodies, but without the potential increased toxicity of small molecule tyrosine kinase inhibitors that can affect both intracellular signalling molecules as well as receptor tyrosine kinases. Moreover, understanding the mechanism of binding of this peptide to these receptors could pave the way for the rational design of drugs that target very specific groups of tyrosine kinase receptors.

Acknowledgments This work was supported by grants from Yorkshire Cancer Research (S303) and the University of Sheffield (Knowledge Transfer Fund).

Conflict of interest The authors declare no conflict of interest.
Ethical approval All animal studies were reviewed and approved by the local Project Award and Amendments Committees and studies were carried out under license from the UK Home Office, Animals Scientific Procedures Act (1986). Human synovial cells were isolated from rheumatoid arthritis patient biopsies with informed consent under ethics approval SSREC/03/106 and in compliance with the Declaration of Helsinki protocols.

Open Access This article is distributed under the terms of the Creative Commons Attribution License which permits any use, distribution, and reproduction in any medium, provided the original author(s) and the source are credited.

\section{References}

1. Waltenberger J, Claesson-Welsh L, Siegbahn A, Shibuya M, Heldin CH (1994) Different signal transduction properties of KDR and Flt1, two receptors for vascular endothelial growth factor. J Biol Chem 269(43):26988-26995

2. Rundhaug JE (2005) Matrix metalloproteinases and angiogenesis. J Cell Mol Med 9(2):267-285

3. Fassina G, Ferrari N, Brigati C, Benelli R, Santi L, Noonan DM, Albini A (2000) Tissue inhibitors of metalloproteases: regulation and biological activities. Clin Exp Metastasis 18(2):111-120

4. Qi JH, Ebrahem Q, Moore N, Murphy G, Claesson-Welsh L, Bond M, Baker A, Anand-Apte B (2003) A novel function for tissue inhibitor of metalloproteinases-3 (TIMP3): inhibition of angiogenesis by blockage of VEGF binding to VEGF receptor-2. Nat Med 9(4):407-415

5. Langton KP, McKie N, Curtis A, Goodship JA, Bond PM, Barker MD, Clarke M (2000) A novel tissue inhibitor of metalloproteinases-3 mutation reveals a common molecular phenotype in Sorsby's fundus dystrophy. J Biol Chem 275(35):27027-27031

6. Bootle-Wilbraham CA, Tazzyman S, Marshall JM, Lewis CE (2000) Fibrinogen E-fragment inhibits the migration and tubule formation of human dermal microvascular endothelial cells in vitro. Cancer Res 60(17):4719-4724

7. Langton KP, Barker MD, McKie N (1998) Localization of the functional domains of human tissue inhibitor of metalloproteinases-3 (TIMP-3) and the effects of a Sorsby's fundus dystrophy mutation. J Biol Chem 273:16778-16781

8. Staton CA, Stribbling SM, Garcia-Echeverria C, Bury JP, Tazzyman S, Lewis CE, Brown NJ (2007) Identification of key residues involved in mediating the in vivo anti-tumor/anti-endothelial activity of Alphastatin. J Thromb Haemost 5(4):846-854

9. Chabottaux V, Sounni NE, Pennington CJ, English WR, van den Brule F, Blacher S, Gilles C, Munaut C, Maquoi E, Lopez-Otin C, Murphy G, Edwards DR, Foidart JM, Noel A (2006) Membranetype 4 matrix metalloproteinase promotes breast cancer growth and metastases. Cancer Res 66(10):5165-5172. doi:10.1158/ 0008-5472.can-05-3012

10. Patel HB, Dawson B, Humby F, Blades M, Pitzalis C, Burnet M, Seed M (2010) Animal Models of rheumatoid arthritis. In: Gilroy D, Serhan C (eds) Fundamentals of inflammation. Cambridge University Press, Cambridge, pp 384-441

11. Gomis-Ruth FX, Maskos K, Betz M, Bergner A, Huber R, Suzuki K, Yoshida N, Nagase H, Brew K, Bourenkov GP, Bartunik H, Bode W (1997) Mechanism of inhibition of the human matrix metalloproteinase stromelysin-1 by TIMP-1. Nature 389(6646): $77-81$

12. Maskos K, Lang R, Tschesche H, Bode W (2007) Flexibility and variability of TIMP binding: X-ray structure of the complex 
between collagenase-3/MMP-13 and TIMP-2. J Mol Biol 366(4):1222-1231. doi:10.1016/j.jmb.2006.11.072

13. Tuuttila A, Morgunova E, Bergmann U, Lindqvist Y, Maskos K, Fernandez-Catalan C, Bode W, Tryggvason K, Schneider G (1998) Three-dimensional structure of human tissue inhibitor of metalloproteinases-2 at 2.1 A resolution. J Mol Biol 284(4): $1133-1140$

14. Wisniewska M, Goettig P, Maskos K, Belouski E, Winters D, Hecht R, Black R, Bode W (2008) Structural determinants of the ADAM inhibition by TIMP-3: crystal structure of the TACE-NTIMP-3 complex. J Mol Biol 381(5):1307-1319. doi:10.1016/j. jmb.2008.06.088

15. Kelley LA, Sternberg MJ (2009) Protein structure prediction on the Web: a case study using the Phyre server. Nat Protoc 4(3):363-371. doi:10.1038/nprot.2009.2

16. Mintseris J, Pierce B, Wiehe K, Anderson R, Chen R, Weng Z (2007) Integrating statistical pair potentials into protein complex prediction. Proteins 69(3):511-520. doi:10.1002/prot.21502

17. Brozzo MS, Bjelic S, Kisko K, Schleier T, Leppanen VM, Alitalo K, Winkler FK, Ballmer-Hofer K (2012) Thermodynamic and structural description of allosterically regulated VEGFR-2 dimerization. Blood 119(7):1781-1788. doi:10.1182/blood-201111-390922

18. Di Benedetto M, Starzec A, Vassy R, Perret GY, Crepin M (2008) Distinct heparin binding sites on VEGF165 and its receptors revealed by their interaction with a non sulfated glycoaminoglycan (NaPaC). Biochim Biophys Acta 1780(4):723-732. doi:10.1016/j.bbagen.2008.01.015

19. Gitay-Goren H, Soker S, Vlodavsky I, Neufeld G (1992) The binding of vascular endothelial growth factor to its receptors is dependent on cell surface-associated heparin-like molecules. J Biol Chem 267(9):6093-6098

20. Yu WH, Yu S, Meng Q, Brew K, Woessner JF Jr (2000) TIMP-3 binds to sulfated glycosaminoglycans of the extracellular matrix. J Biol Chem 275(40):31226-31232

21. Kim WU, Kang SS, Yoo SA, Hong KH, Bae DG, Lee MS, Hong SW, Chae CB, Cho CS (2006) Interaction of vascular endothelial growth factor 165 with neuropilin-1 protects rheumatoid synoviocytes from apoptotic death by regulating Bcl-2 expression and Bax translocation. J Immunol 177(8):5727-5735

22. Hoegy SE, Oh HR, Corcoran ML, Stetler-Stevenson WG (2001) Tissue inhibitor of metalloproteinases-2 (TIMP-2) suppresses TKR-growth factor signaling independent of metalloproteinase inhibition. J Biol Chem 276(5):3203-3214

23. Seo DW, Li H, Guedez L, Wingfield PT, Diaz T, Salloum R, Wei BY, Stetler-Stevenson WG (2003) TIMP-2 mediated inhibition of angiogenesis: an MMP-independent mechanism. Cell 114(2): $171-180$

24. Janssen A, Hoellenriegel J, Fogarasi M, Schrewe H, Seeliger M, Tamm E, Ohlmann A, May CA, Weber BH, Stohr H (2008) Abnormal vessel formation in the choroid of mice lacking tissue inhibitor of metalloprotease-3. Invest Ophthalmol Vis Sci 49(7): 2812-2822. doi:10.1167/iovs.07-1444

25. Ebrahem Q, Qi JH, Sugimoto M, Ali M, Sears J, Cutler A, Khokha R, Vasanji A, Anand-Apte B (2011) Increased neovascularization in mice lacking tissue inhibitor of metalloproteinases-3. Invest Ophthalmol Vis Sci 52(9):6117-6123. doi:10.1167/ iovs.10-5899

26. Sivaprasad S, Webster AR, Egan CA, Bird AC, Tufail A (2008) Clinical course and treatment outcomes of Sorsby fundus dystrophy. Am J Ophthalmol 146(2):228-234

27. Worley JR, Thompkins PB, Lee MH, Hutton M, Soloway P, Edwards DR, Murphy G, Knauper V (2003) Sequence motifs of tissue inhibitor of metalloproteinases 2 (TIMP-2) determining progelatinase A (proMMP-2) binding and activation by membrane-type metalloproteinase 1 (MT1-MMP). Biochem J 372(Pt 3):799-809. doi: $10.1042 / b j 20021573$

28. Fuh G, Li B, Crowley C, Cunningham B, Wells JA (1998) Requirements for binding and signaling of the kinase domain receptor for vascular endothelial growth factor. J Biol Chem 273(18):11197-11204

29. AnandApte B, Pepper MS, Voest E, Montesano R, Olsen B, Murphy G, Apte SS, Zetter B (1997) Inhibition of angiogenesis by tissue inhibitor of metalloproteinase-3. Invest Ophthalmol Vis Sci 38(5):817-823

30. Tille JC, Wood J, Mandriota SJ, Schnell C, Ferrari S, Mestan J, Zhu Z, Witte L, Pepper MS (2001) Vascular endothelial growth factor (VEGF) receptor-2 antagonists inhibit VEGF- and basic fibroblast growth factor-induced angiogenesis in vivo and in vitro. J Pharmacol Exp Ther 299(3):1073-1085

31. Robinson DR, Wu YM, Lin SF (2000) The protein tyrosine kinase family of the human genome. Oncogene 19(49):5548-5557. doi:10. 1038/sj.onc. 1203957

32. Qi JH, Ebrahem Q, Ali M, Cutler A, Bell B, Prayson N, Sears J, Knauper V, Murphy G, Anand-Apte B (2013) Tissue inhibitor of metalloproteinases-3 peptides inhibit angiogenesis and choroidal neovascularization in mice. PLoS One 8(3):e55667. doi:10.1371/ journal.pone.0055667

33. Matei D, Kelich S, Cao L, Menning N, Emerson RE, Rao J, Jeng MH, Sledge GW (2007) PDGF BB induces VEGF secretion in ovarian cancer. Cancer Biol Ther 6(12):1951-1959

34. Cao Y, Cao R, Hedlund EM (2008) Regulation of tumor angiogenesis and metastasis by FGF and PDGF signaling pathways. J Mol Med (Berl) 86(7):785-789. doi:10.1007/s00109-008-0337-z

35. Manabe N, Oda H, Nakamura K, Kuga Y, Uchida S, Kawaguchi $\mathrm{H}$ (1999) Involvement of fibroblast growth factor-2 in joint destruction of rheumatoid arthritis patients. Rheumatology (Oxford) 38(8):714-720

36. Rosengren S, Corr M, Boyle DL (2010) Platelet-derived growth factor and transforming growth factor beta synergistically potentiate inflammatory mediator synthesis by fibroblast-like synoviocytes. Arthritis Res Ther 12(2):R65. doi:10.1186/ar2981

37. Jackson JR, Seed MP, Kircher CH, Willoughby DA, Winkler JD (1997) The codependence of angiogenesis and chronic inflammation. FASEB J 11(6):457-465

38. Alam C, Colville-Nash P, Seed M (2008) Modelling angiogenesis in inflammation. In: Seed MP, Walsh DA (eds) Angiogenesis in inflammation: mechanisms and clinical correlates. Progress in Inflammation Research, Birkhäuser Basel, pp 99-148

39. De Bandt M, Ben Mahdi MH, Ollivier V, Grossin M, Dupuis M, Gaudry M, Bohlen P, Lipson KE, Rice A, Wu Y, GougerotPocidalo MA, Pasquier C (2003) Blockade of vascular endothelial growth factor receptor I (VEGF-RI), but not VEGF-RII, suppresses joint destruction in the $\mathrm{K} / \mathrm{BxN}$ model of rheumatoid arthritis. J Immunol 171(9):4853-4859

40. Matsumoto Y, Tanaka K, Hirata G, Hanada M, Matsuda S, Shuto T, Iwamoto Y (2002) Possible involvement of the vascular endothelial growth factor-Flt-1-focal adhesion kinase pathway in chemotaxis and the cell proliferation of osteoclast precursor cells in arthritic joints. J Immunol 168(11):5824-5831

41. Kazazi-Hyseni F, Beijnen JH, Schellens JH (2010) Bevacizumab. Oncologist 15(8):819-825. doi:10.1634/theoncologist.2009-0317

42. Kim A, Balis FM, Widemann BC (2009) Sorafenib and sunitinib. Oncologist 14(8):800-805. doi:10.1634/theoncologist.2009-0088

43. Lohela M, Bry M, Tammela T, Alitalo K (2009) VEGFs and receptors involved in angiogenesis versus lymphangiogenesis. Curr Opin Cell Biol 21(2):154-165. doi:10.1016/j.ceb.2008.12. 012

44. Fischer C, Jonckx B, Mazzone M, Zacchigna S, Loges S, Pattarini L, Chorianopoulos E, Liesenborghs L, Koch M, De Mol M, 
Autiero M, Wyns S, Plaisance S, Moons L, van Rooijen N, Giacca M, Stassen JM, Dewerchin M, Collen D, Carmeliet P (2007) Anti-PlGF inhibits growth of $\operatorname{VEGF(R)-inhibitor-resistant~tumors~}$ without affecting healthy vessels. Cell 131(3):463-475. doi:10. 1016/j.cell.2007.08.038
45. Bergers G, Hanahan D (2008) Modes of resistance to antiangiogenic therapy. Nat Rev Cancer 8(8):592-603 